\title{
Recombinant vaccinia viruses expressing immunoglobulin variable regions efficiently and selectively protect mice against tumoral B-cell growth
}

\author{
Sémia BenAmmar-Ceccoli, ${ }^{1}$ Sophie Humblot, ${ }^{1}$ Rachel Crouzier, ${ }^{1}$ Bruce Acres, ${ }^{2}$ \\ Marie-Paule Kieny, ${ }^{2}$ Dorothee Herlyn, ${ }^{3}$ Jean Louis Pasquali, ${ }^{1}$ and Thierry Martin ${ }^{1}$ \\ ${ }^{1}$ Laboratoire d'Immunopathologie, Institut d'Immuno-hématologie, Hôpital Civil, Strasbourg 67091, France; \\ ${ }^{2}$ Transgène, Strasbourg 67082, France; and ${ }^{3}$ Wistar Institute, Philadelphia, Pennsylvania 19104.
}

\begin{abstract}
The variable regions of the immunoglobulin ( $\mathrm{Ig}$ ) expressed on the surface of a malignant B cell can be considered tumor-specific antigens and, as such, could be targets for immunotherapeutic approaches. However, because until now the immunization procedures have been complex and have given only partial protection, it was necessary to find new methods of immunotherapy. Here, we present a successful method of vaccination against B - cell tumors in a murine model. We produced recombinant vaccinia viruses (rVV) expressing the heavy and the light chain of surface Ig of a patient's malignant B cells and we tested the ability of these rVV to protect immunized mice against tumor growth of transfectomas producing the same human Ig. The protection of the mice was complete and specific to the variable region of the immunizing heavy chain although specific lymphoproliferative and cytotoxic responses were not detectable in vitro. The protection was strictly dependent on the presence of CD4 T cells and asialo GM1 + cells. Furthermore, tumor protection clearly required $\gamma$-interferon and was partially inhibited by blocking the Fas-Fas ligand interaction. We also show, in a murine syngeneic model, that rVV expressing a poorly mutated Ig protects against the growth of Ig-producing tumor. Cancer Gene Therapy (2001) 8, 815-826
\end{abstract}

Key words: Tumor vaccination; $B$-cell malignancies; recombinant vaccinia virus; anti-idiotypic response.

$\mathrm{H}$ uman B-cell malignancies constitute about $75 \%$ of the cases of lymphoproliferative diseases in adults and include B-cell chronic lymphocytic leukemia (B-CLL), hairy cell leukemia, diverse non-Hodgkin's lymphomas, and multiple myeloma. ${ }^{1}$ These B-cell malignant tumors are the result of single clone proliferation of cells expressing surface markers, of which the surface immunoglobulin (sIg) is the most specific: in fact, the genetic processes, which occur during B-cell ontogeny, give rise to an extremely diverse Ig repertoire, with each Ig being considered a tumor-specific antigen in B-cell malignancies.

Both active and passive approaches to immunotherapy in B lymphoproliferative diseases are of interest. The goal of active immunotherapy is to induce or to stimulate the cellular and/or the humoral anti-idiotypic, antitumor immunity. It gave promising results in murine models and clinical trials using tumor-originating $\mathrm{Ig}^{2-7}$ and more recently using $\mathrm{Ig}$ processed by dendritic cells ${ }^{8,9}$ or DNA coding for the Ig in question. ${ }^{10-12}$ For instance, King et al induced protective immunity against murine lymphoma and myeloma using DNA vaccines containing tumor-derived single-chain Fv fused with the gene encoding the fragment $\mathrm{C}$ of tetanus

Received July 13, 2001.

Address correspondence and reprint requests to Dr. Thierry Martin, Laboratoire d'Immunopathologie, Institut d'Immuno-hématologie, Hôpital Civil, 1 Place de l'Hôpital, Strasbourg 67091, France. E-mail address: thierry.martin@hemato-ulp.u-strasbg.fr toxin. What could be the theoretical limitations of active immunotherapy? In the first place, it may be conjectured that self-antigens induce tolerance by causing the functional silencing or the physical elimination of high-avidity T cells. If this conjecture is the case, it could be of particular importance for nonmutated antigens, which constitute very weak tumor antigens. In the cases of B-cell malignancies, it will probably be more difficult to induce an immune response against germline variable region products (like some B-CLL ${ }^{13-15}$ ) than against mutated forms (like follicular lymphomas ${ }^{16,17}$ ). In the second place, the vaccination protocols were shown to be able to induce anti-idiotypic responses in the host, but were possibly not entirely satisfying in activating low-avidity $\mathrm{T}$ cells or other effector cells. An interesting alternative approach consists of the use of a recombinant vaccinia virus ( $\mathrm{rVV}$ ), which is known to offer several advantages as an immunization vector: (a) it can accommodate up to $26 \mathrm{kbp}$ of foreign DNA, without loss of infectivity; (b) it is easier and less time-consuming to construct and produce than to purify large amounts of tumor-associated protein; (c) it can infect a large variety of cell lines; and (d) it is highly efficient in inducing long-lasting humoral and cell-mediated immunity and could therefore avoid the necessity of using other immune stimuli. ${ }^{18-21}$

In order to test the ability of the vaccinia virus (VV) approach, we developed a two-step strategy: in the first step, we cloned the variable region genes of an Ig originating from 
the leukemic B cells of a single patient ARN suffering from $\mathrm{B}-\mathrm{CLL}{ }^{22}$ The rearranged genes coding for the light (L) and heavy chains $(\mathrm{H})$ were then cloned into $\mathrm{VV}$ expression cassette vectors. The rVV were evaluated for their capacity to protect mice against the tumor growth of transfectomas producing the same human Ig. In the second step, we studied the ability of this vaccinia approach to circumvent the possible immune tolerance against poorly mutated variable regions of Ig by using a syngeneic murine model. ${ }^{23,24}$

\section{MATERIALS AND METHODS}

\section{Recombinant vaccinia viruses}

$r V V$ expressing the human Ig genes. The preparation of the leukemic B cells of the patient ARN, the amplification, and the sequencing of the rearranged genes coding for the $\mathrm{H}$ and the $\mathrm{L}$ chains expressed by these cells have been described elsewhere. ${ }^{22}$ For the construction of the VV expression vectors, total RNA were isolated from the peripheral blood lymphocytes of the patient ARN, extracted with phenol/ chloroform, and precipitated with ethanol. cDNA were then synthesized using reverse transcriptase (Boehringer Mannheim Biochemicals, Mannheim, Germany) and primers complementary to the $3^{\prime}$ end of the $\mathrm{C} \kappa$ constant region and of the $\mathrm{C} \mu 2$ exon. The heavy-chain cDNA was subjected to polymerase chain reaction amplification using Taq DNA polymerase (Perkin-Elmer Cetus, Emeryville, CA) and primers specific to the VHII leader region and the $3^{\prime}$ end of the $\mathrm{C} \mu 2$ constant region. The $\mathrm{L}$ chain cDNA was amplified using primers specific to the $\mathrm{V} \kappa \mathrm{III}$ leader region and the $3^{\prime}$ end of the $\mathrm{C} \kappa$ constant region. The $\mathrm{H}$ chain polymerase chain reaction product was cloned in the plasmid pTG186poly ${ }^{25}$ upstream of the sequence coding for the intracytoplasmic and transmembrane domains of rabies glycoprotein, ${ }^{26}$ giving pVVHt (Fig 1A). The $\mathrm{V} \kappa \mathrm{J} \kappa \mathrm{C} \kappa$ gene complex was cloned in the plasmid pTG186poly giving the pVVL vector (Fig 1B). Sequencing was carried out using primers specific to both the $3^{\prime}$ and $5^{\prime}$ ends to check that unwanted mutations were not introduced into the human sequences during the different procedures. The rVV were generated by in vitro homologous recombination of VV DNA (Copenhagen strain) with the plasmids pVVL, pVVHt, and pTG186poly in primary chicken fibroblasts, as described. ${ }^{27}$ This resulted in the generation of the VVL, which synthesizes the ARN-Ig L chain, the VVHt, which produces the ARN-Ig H chain, and the VVTG186, which does not produce any recombinant protein.

$r V V$ expressing the murine Ig genes. Three rVV were used in this study and were generated by Transgene (Strasbourg, France) from the Copenhagen strain. The complete $\mathrm{H}$ and $\mathrm{L}$ chains of the monoclonal antibody (mAb) $\mathrm{CO} 17-1 \mathrm{~A}^{23,24}$ were introduced into the genome of the VV. To obtain the pTG1142 plasmid, the cDNA coding for the $\mathrm{H}$ and $\mathrm{L}$ chains were introduced into the plasmid pTG186poly ${ }^{25}$ downstream of two copies of the 7.5 early/late vaccinia promoter. The two expression blocks were placed in opposite orientations in order to avoid homologous recombination between the two copies of the promoter. For the construction of the pTG2179, the cDNA coding for the $\mathrm{H}$ chain of the mAb CO17-1A was cloned in phase, upstream of the sequence coding for the transmembrane an intracytoplasmic domains of rabies glycoprotein. ${ }^{26}$ As for the pTG1142, the cDNA coding for the $\mathrm{L}$ and modified $\mathrm{H}$ chains were introduced into plasmid pTG186 downstream of the 7.5 vaccinia promoter, in opposite orientations. In vitro homologous recombination in primary chicken fibroblasts ${ }^{27}$ of VV DNA with the plasmids pTG186poly, pTG1142, and pTG2179 resulted in the generation of VVTG186, VVTG1142, which synthesizes a secreted version of mAb CO17-1A, and VVTG2179, which produces a membrane-anchored version of the same $\mathrm{mAb}$. The foreign genes inserted into the VV thymidine kinase (TK) gene are controlled by the 7.5 vaccinia promoter, and generate TK - progeny. The expression of the mAb CO17-1A at the membrane of BHK-21 cells infected by VVTG2179 was verified by FACScan analysis. The production of the mAb CO17-1A by BHK-21 cells infected by VVTG1142 was measured in the culture supernatant by enzyme-linked immunosorbent assay (ELISA).

\section{Transfectoma cells}

The rearranged VHDJH gene complex was cloned in the expression vector pRTM1 as described, ${ }^{28}$ giving the pRTM1-ARN vector. The $\mathrm{V} \kappa \mathrm{J} \kappa \mathrm{C} \kappa$ gene complex was cloned in the expression vector pZeoSV (Invitrogen, San Diego, CA), resulting in the pZeoSV-ARN vector. The pRTM1-ARN and pZeoSV-ARN vectors were linearized and purified before being suspended in sterile TE $(10 \mathrm{mM}$ Tris $-\mathrm{Cl}, \mathrm{pH} 8,1 \mathrm{mM}$ EDTA). Two micrograms of linearized DNA was electroporated into $1.5 \times 10^{7} \mathrm{P} 3 \mathrm{X} 63 . \mathrm{Ag} 8.653$ cells
Figure 1. rVV expression vectors. The cDNA coding for the IgM - ARN truncated $\mathrm{H}$ chain (A) and for the $\kappa$ light chain (B) were introduced into the VV sequence (VV-hindJ), downstream of the P7.5 early/late vaccinia virus promoter, using $\mathrm{BamHI}$ and Sacl restriction sites. Striped boxes represent human sequences; the solid box represents the rabies transmembrane sequence (TS); AmpR designates the ampicillin gene resistance; the arrows show the directions of gene transcription.
A

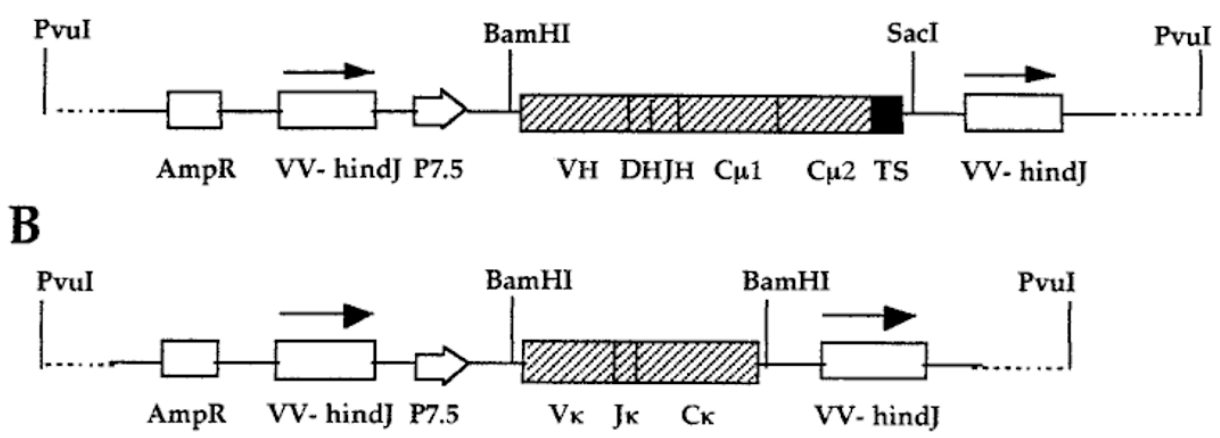


as described. ${ }^{28}$ Two days after electroporation, IgM-ARN transfectoma cells were selected in complete medium supplemented with $1 \mathrm{mg} / \mathrm{mL}$ geneticin (G418) and 0.5 $\mathrm{mg} / \mathrm{mL}$ zeocin (Invitrogen), at $\mathrm{pH}$ 7.6. After selection, IgM-SMI ${ }^{28}$ and IgM-ARN transfectomas were cultured in the same complete medium as the P3X63.Ag8.653 cells: RPMI-1640 (Life Technologies, Cergy Pontoise, France) supplemented with $10 \%$ heat-inactivated fetal calf serum (DAP, Neuf-Brisach, France), $2 \mathrm{mM} \mathrm{L}$-glutamine (Life Technologies), $100 \mathrm{U} / \mathrm{mL}$ penicillin (Life Technologies), and $100 \mu \mathrm{g} / \mathrm{mL}$ streptomycin (Life Technologies).

\section{Cell lines}

The 1083-17-1A murine hybridoma and the baby hamster kidney cells, BHK-21, were supplied by Transgene. The mAb CO17-1A producing hybridoma 1083-17-1A was obtained through fusion of $\mathrm{BALB} / \mathrm{c}$ myeloma P3X63.Ag8.653 cells with splenocytes from BALB/c mice immunized with SW1083, which is a human colorectal carcinoma cell line. ${ }^{29,30}$ All cell cultures were maintained in the medium described above, except BHK-21 baby hamster kidney cells that were cultured in Glasgow medium (Life Technologies) containing $10 \%$ fetal calf serum (FCS).

\section{Flow cytometric analysis}

H97 FITC-labeled mouse antimouse-H-2 ${ }^{\mathrm{d}}$ and $\mathrm{H}-2 \mathrm{~K}^{\mathrm{d}}$, 14.4.4 FITC-labeled mouse antimouse I- $\mathrm{E}^{\mathrm{k}, \mathrm{d}, \mathrm{b}, \mathrm{s}}$, FITClabeled goat antihuman $\kappa$ light chain (Caltag, Burlingame, CA), FITC-labeled goat antihuman $\mu$ heavy chain (Jackson Immunoresearch, West Grove, PA), and biotin-conjugated hamster antimouse Fas (Pharmingen, San Diego, CA), followed by FITC-labeled streptavidin (Caltag), were used for 15 minutes at $4^{\circ} \mathrm{C}$ to stain transfectomas and BHK-21infected cells before being analysed in a Becton Dickinson FACScan, Mountain View, CA. For the cytoplasmic staining of IgM-ARN transfectomas, we used the Fix and Perm kit (Caltag) following the manufacturer's instructions.

\section{Animal immunization and challenge}

Six - to 8 -week -old female BALB/c mice were purchased from Janvier (Le Genest-Saint-Isle, France). Mice were immunized three times at 14 -day intervals, with $10^{7}$ pfu of one of the purified rVV. This was done by tail scarification or intraperitoneal (i.p.) injections with 5 or $200 \mu \mathrm{L}$, respectively, of PBS containing the respective rVV. One week after the last boost, scarified mice were subcutaneously (s.c.) challenged with $40 \times 10^{6}$ IgM-ARN transfectomas or IgMSMI control transfectomas, whereas i.p. immunized mice were injected by i.p. route. In the syngeneic mouse model, mice were challenged by s.c. injection of $20 \times 10^{6} 1083-17$ 1A hybridoma or control cells. The mice were then monitored for tumor growth by measuring perpendicular tumor dimensions with calipers.

\section{Lymphoproliferation assay}

Spleen and lymph node cells were collected 7 days after the third immunization or after the IgM-ARN transfectoma challenge, and CD4 + cells were purified with a MiniMACS magnetic cell sorting kit (Milteniy Biotec, Auburn, CA) using microbeads conjugated with anti-CD4 mAb (Milteniy Biotec). Stimulating cells were resuspended at $5 \times 10^{7}$ cells/ $\mathrm{mL}$ and treated with mitomycin C (Sigma, St. Quentin Fallavier, France) at a final concentration of $50 \mu \mathrm{g} / \mathrm{mL}$ for 20 minutes at $37^{\circ} \mathrm{C}$. Cells were then washed three times in RPMI-1640 before being suspended at a concentration of $10^{5}$ cells $/ \mathrm{mL}$ in culture medium. Purified CD4+ or CD4effector cells (E) were co-cultured for 5 days at $37^{\circ} \mathrm{C}$ with $100 \mu \mathrm{L}$ of stimulating cells (S) treated with mitomycin $\mathrm{C}$ at various $\mathrm{E} / \mathrm{S}$ ratios. Cultures were pulsed with ${ }^{3} \mathrm{H}$-labeled thymidine $(1 \mu \mathrm{Ci} /$ well $)$ (Du Pont/NEN, Les Ulis, France) for the final 18-24 hours of incubation. Tests were run in triplicates, in round-bottom 96 -well polystyrene plates. Cells were collected with a cell harvester, and incorporated radioactivity was measured by liquid scintillation spectroscopy. The stimulation index was calculated for each triplicate by dividing the mean radioactivity of experimental-stimulated cells with that of negative control-stimulated cells.

\section{Cytotoxicity assays}

CD4+ or CD4 - cells were cultured in the presence of mitomycin C-treated IgM-ARN or IgM-SMI transfectoma cells, at ratios of $10 / 1$ or $100 / 1$, with or without IL-2 (Boehringer Mannheim Biochemicals). After 5 days of incubation, cells were harvested and various numbers of effector cells were added to $10^{4}$ target cells that were labeled with $\mathrm{Na}_{2}^{51} \mathrm{CrO}_{4}$ (CIS Biointernational, Gif-sur-Yvette, France) in round-bottom 96-well plates. Four-hour cytolysis assays were performed in triplicates and specific lysis was calculated as follows: \% specific lysis $=($ experimental $\mathrm{cpm}$-spontaneous $\mathrm{cpm}) /($ maximal $\mathrm{cpm}$ - spontaneous $\mathrm{cpm}) \times 100$. Spontaneous lysis was less than $10 \%$ of specific lysis.

\section{Evaluation of the anti-idiotypic humoral response by a cytofluorometric test}

Blood samples were taken from VVHt- and VVTG186immunized mice 7 days after the third immunization or 7 days after the inoculation of the IgM-ARN transfectoma cells. The presence of anti-idiotypic antibodies was tested by determining the capacity of the sera to bind to surface IgM expressed by the leukemic B cells of the patient ARN, after neutralization of the $\mathrm{Ab}$ directed against the $\mathrm{C} \mu$ human region. Leukemic cells expressing sIgM, from other CLL patients, were used as controls. Serum dilution of $1 / 50$ was incubated for 20 minutes at room temperature with $10 \mu \mathrm{g} / \mathrm{mL}$ human IgM (Sigma). Fifty microliters of this mixture was added to $2 \times 10^{5}$ CLL lymphocytes for 30 minutes at $4{ }^{\circ} \mathrm{C}$. After washing, cells were allowed to react with an FITClabeled rabbit antimouse $\operatorname{IgG}\left(\mathrm{F}\left(\mathrm{ab}^{\prime}\right)_{2}\right)$ antibody (Jackson Immunoresearch) for 15 minutes at $4{ }^{\circ} \mathrm{C}$. Cells were washed again and analysed using a Becton Dickinson FACScan.

\section{Evaluation of the anti-idiotypic humoral response using an ELISA assay}

Plates were coated with $1 \mu \mathrm{g} / \mathrm{mL}$ goat antihuman $(\mathrm{Fc} 5 \mu)$ (Jackson Immunoresearch) and incubated for 1 hour at $37^{\circ} \mathrm{C}$. 
A

CONTROL NON IMMUNIZED MICE IgM-ARN TRANSFECTOMA CHALLENGE

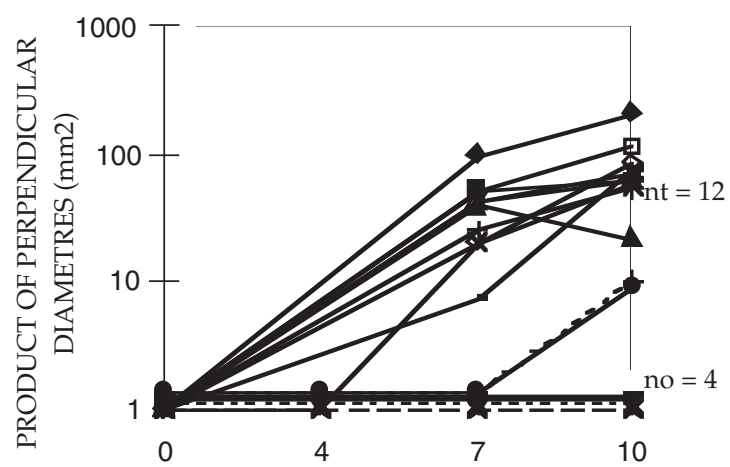

DAYS POST TUMOR TRANSPLANT

B

VVTG186 IMMUNIZED MICE IgM-ARN TRANSFECTOMA CHALLENGE

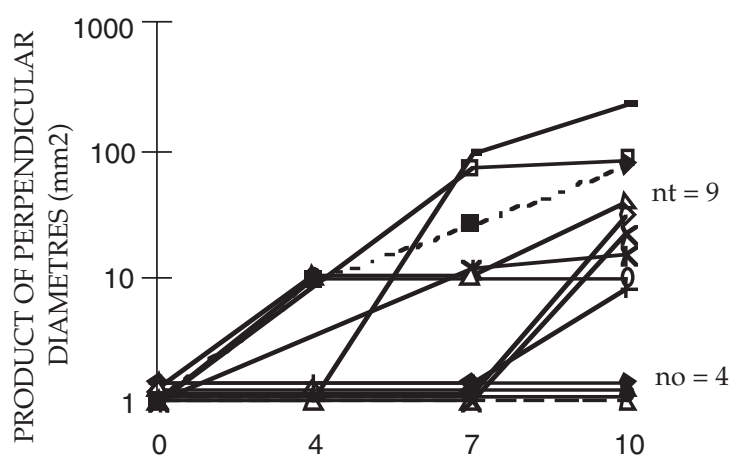

DAYS POST TUMOR TRANSPLANT

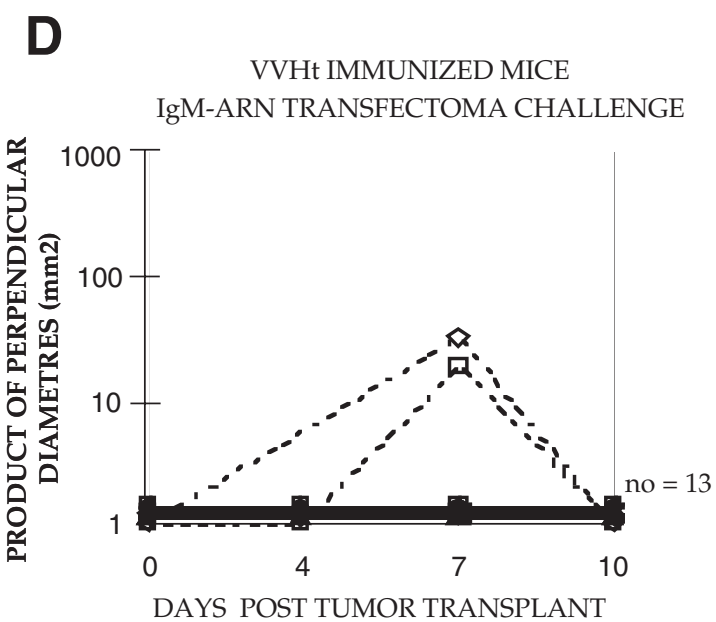

E
VVHt IMMUNIZED MICE IgM-SMI TRANSFECTOMA CHALLENGE

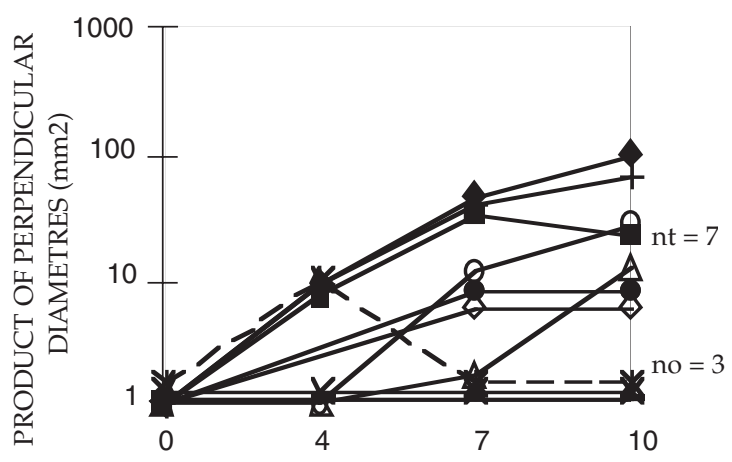

DAYS POST TUMOR TRANSPLANT

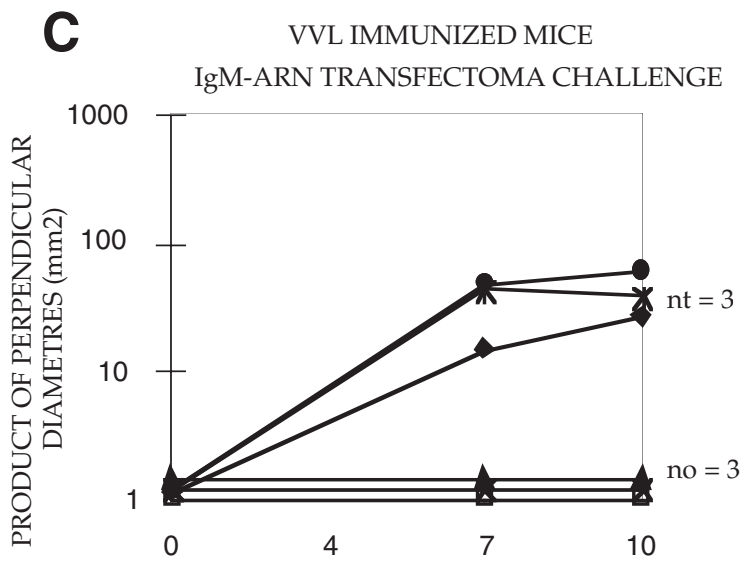

DAYS POST TUMORAL TRANSPLANT

Figure 2. VVHt immunization induces protection against transfectoma growth. BALB/c mice were immunized by tail scarification three times at 14- day intervals. Seven days after the last boost, the mice were challenged by s.c. inoculation of $40 \times 10^{6}$ IgM-ARN transfectoma cells (A, B, C, D) or IgM-SMI transfectoma cells (E). Tumor size was estimated as the product of perpendicular diameters. (A) Sixteen nonimmunized control mice. (B) Thirteen control VVTG186-immunized mice. (C) Six mice immunized with VVL expressing IgM-ARN $\kappa$ light chain. (D) Thirteen mice immunized with VVHt expressing IgM-ARN H chain. (E) Ten mice immunized with VVHt before being challenged with IgM-SMI transfectoma cells. The number of mice bearing tumors ( $\mathrm{nt}$ ) and the number of mice without tumors (no), 10 days after challenge, are indicated. 
After PBS-BSA 1\% saturation, $50 \mathrm{ng} / \mathrm{mL}$ of human $\operatorname{IgM}$ (Sigma) or purified IgM-ARN was added and incubated overnight at $4^{\circ} \mathrm{C}$. Suitable dilutions $(1 / 50,1 / 250,1 / 1000)$ of the serum samples described above or $1 \mu \mathrm{g} / \mathrm{mL}$ of a control mouse antihuman IgM (Jackson Immunoresearch) was added and incubated for 1 hour at $37^{\circ} \mathrm{C}$. Bound antibodies were then detected with peroxidase-conjugated goat antimouse $\operatorname{IgG}(\mathrm{H}+\mathrm{L})$ (Jackson Immunoresearch) at $16 \mathrm{ng} / \mathrm{mL}$ for 1 hour at $37^{\circ} \mathrm{C}$. In order to determine the presence of anti-idiotypic antibodies, IgM-ARN absorbance values were compared to total human $\operatorname{IgM}$ absorbance values.

\section{In vivo blocking assays}

Fifty microliters of rat antibodies in ascite form directed against mouse CD4 (YTS177.9.6.1) ${ }^{31}$ and mouse CD8 (YTS105.18.10) ${ }^{31}$ was administrated by i.p. route in VVHtimmunized mice following the schedules in Figure 6, A and B. For NK depletion, $30 \mu \mathrm{L}$ of rabbit antiasialo GM1 (Wako BioProducts, Neuss, Germany) was injected i.p. in immunized mice (Fig 6C). Immunized mice were also treated with rat antimouse $\gamma$-interferon (IFN- $\gamma$ ) mAb (R46A2, $1 \mu \mathrm{g} /$ mouse) (Pharmingen) (Fig 6D) or with hamster antimouse FasL mAb (MFL1, $2 \mu \mathrm{g} /$ mouse) ${ }^{32}$ (Fig 6E). All mice were challenged with $40 \times 10^{6} \mathrm{IgM}-\mathrm{ARN}$ transfectoma cells.

Statistical analysis

$P$ values were calculated with Fisher's exact test.

\section{RESULTS}

\section{Production of the rVV}

In vitro homologous recombination of VV DNA (Copenhagen strain; see Materials and Methods) with pVVHt and pVVL, in primary chicken fibroblasts, resulted in the generation of the viruses VVHt and VVL, respectively. After in vitro co-infection of BHK-21 hamster cells with VVHt and VVL, the IgM-ARN was detected at the cell membrane by FACScan analysis (data not shown). When BHK-21 cells were infected in vitro with VVL alone, the human $\mathrm{L}$ chain was secreted in the supernatants $(5 \mu \mathrm{g} / \mathrm{mL})$, but when the cells were infected with VVHt, no $\mathrm{H}$ chain was detectable in the supernatants or at the cell membrane, leading to the conclusion that the protein was intracellularly processed. In order to design an efficient minimal immunization procedure, we tested VVL and VVHt VVs, separately.

\section{Tumor challenges with IgM-ARN producing transfectomas}

We produced transfectoma cells by electroporating the IgMARN expression vectors (pRTM1-ARN and pZeoSVARN) into nonsecreting murine myeloma P3X63Ag8.653 cells, as described. ${ }^{28,33}$ The transfectomas were shown to express low levels of class II MHC molecules (I-E ${ }^{\mathrm{d}}$ ) and high levels of class I MHC molecules $\left(\mathrm{H}-2 \mathrm{D}^{\mathrm{d}}\right.$ and $\left.\mathrm{H}-2 \mathrm{~K}^{\mathrm{d}}\right)$ (data not shown). They produced cytoplasmic $\mu$ and $\kappa$ chains, secreted intact IgM-ARN, but did not express it at the cell surface (data not shown). These transfectoma cells, when s.c. or i.p. injected into syngeneic BALB/c mice, produced measurable tumors within 7-10 days in at least $75 \%$ of cases (Fig 2A). When the cells were s.c. injected, the tumors expanded locally but did not metastasize. From day 15 , approximately $20 \%$ of the tumors underwent necrosis associated with cutaneous ulceration. The i.p. cell injection resulted in the rapid appearance of solid tumors in the peritoneal cavity. The mice were immunized three times at 14-day intervals, with the control VVTG186 or with VVHt expressing the transmembrane $\mathrm{H}$ chain or with VVL expressing the L chain.

Figure 2 shows complete protection against tumor growth of the IgM-ARN transfectoma cells in mice immunized with VVHt expressing the IgM-ARN H chain (Fig 2D), but not with the control VVTG186 (Fig 2B) $(P=.0005)$. Only
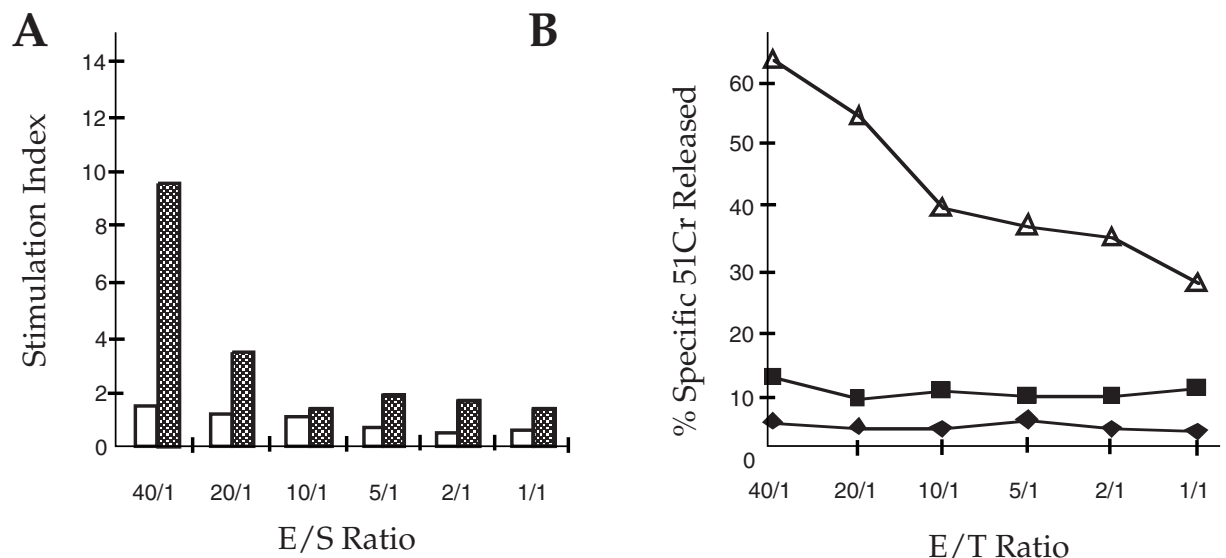

Figure 3. Lack of cellular responses detectable in vitro after VVHt immunization. Mice were immunized by tail scarification with VVHt or with the wild-type virus VVTG186. Seven days after the third immunization or after the IgM-ARN transfectoma inoculation, spleen and lymph node cells were harvested. (A) Lymphoproliferative response: Effector cells were co-cultured with mitomycin C-treated IgM-ARN transfectomas, or with IgM-SMI control transfectomas, or with allotypic control cells (C57BL/ 6 mice splenocytes). Proliferation was assessed by $\left[{ }^{3} \mathrm{H}\right]$ thymidine incorporation and shown as mean stimulation index

(SI) for each triplicate well (see Materials and Methods): Open histograms designate the SI when the experimental-stimulating cells are the IgMARN transfectomas and grey histograms designate the SI when the experimental-stimulating cells are the allotypic control cells. (B) Cytotoxic response: Lytic activity was assessed against IgM-ARN transfectomas ( $\bullet$ ), IgM-SMI transfectomas ( $\boldsymbol{\square}$ ), and C57BL/6 lymphoblasts (alloreactive control) $(\triangle)$. These experiments were carried out using the splenocytes of a VVHt-immunized mouse and were representative of the two groups of immunized mice after or before tumor challenge. The same results were obtained using the lymph node cells. 
partial, nonsignificant protection was observed using the $\mathrm{L}$ chain construct $(P=.6)$ (Fig $2 \mathrm{C})$. No protection was observed in mice immunized with the ARN $\mathrm{H}$ chain construct and injected with tranfectoma cells expressing a human IgM with different variable regions (IgM-SMI) ${ }^{28}$ (Fig 2E). Mice injected i.p. with tumor cells were similarly protected by the VVHt virus (data not shown) $(P=.005)$. These experiments show clearly that the tumor protection is complete and specific to the IgM-ARN H chain variable region.

In vivo tumor protection is not associated with in vitro detectable specific $T$-cell proliferation or cytotoxicity

Up until now, the mechanisms of tumor growth protection in different murine models of B-cell malignancies and in human lymphomas have only been partially investigated and have given contrasting results depending on the model and on the immunization protocol. However, both specific T-cell lymphoproliferation and humoral responses have been described. Despite the in vivo efficiency of our $\mathrm{H}$ chain VV construct, we were unable to detect a significant increase of $\mathrm{T}$-cell proliferation when measuring $\left[{ }^{3} \mathrm{H}\right]$ thymidine incorporation into splenic or lymph node $\mathrm{T}$ cells in the presence of mytomicin C-treated IgM-ARN transfectoma cells (Fig 3A). We also failed to show any specific $\mathrm{T}$-cell cytotoxicity (chromium release assay) when effector cells (CD4+ or CD4 - cells) were cultured with or without IL-2 for 5 days in the presence of the target cells (Fig 3B). The harvesting of the effector cells after the last immunization or after the tumor challenge did not affect these results.

Antibodies against the tumor Ig are not detectable

Concerning the B-cell response in immunized mice, the antibodies that would be required for blocking experiments are not available, but cytofluorometric analysis of ARN leukemic cells (expressing the IgM-ARN at the membrane) or of control leukemic B cells incubated with the sera of the animals did not show a clear specific antibody response against IgM-ARN (data not shown). In the same way, the ELISA assay did not highlight significant quantities of antibodies directed against the IgM-ARN variable regions (data not shown).

\section{$C D 4$, but not CD8, $T$ cells are critical for tumor protection}

In order to determine which effector cells were engaged in the tumor protection, we performed in vivo mAb blocking experiments prior to the tumor challenge of immunized mice. When mice were injected with blocking amounts of anti$\mathrm{CD} 4 \mathrm{mAb}$ (see the experiment schedule in Fig 4), the tumor protection was abolished (Fig 5A) $(P=.0005)$. On the contrary, the anti-CD8 blocking assay failed to reverse significantly the protection against the tumor growth (Fig 5B) despite an efficient CD8 binding for 15 days (Ref. ${ }^{34}$ and data not shown).

Considering the absence of CD8 T-cell requirement in the observed protection, we then tested the effect of NK depletion. It is known that treatment of mice with antiasialo GM1 antibodies ${ }^{35}$ results in a total abolition of cytotoxic

\section{A (anti CD4)}

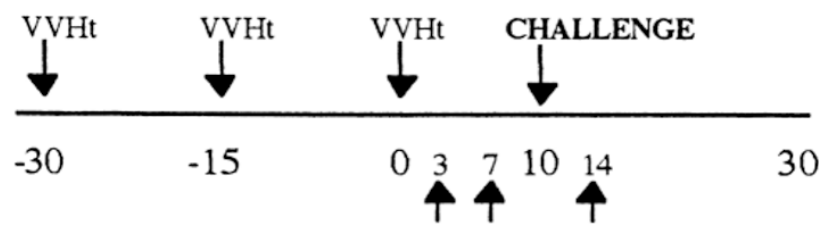

\section{B (anti CD8)}

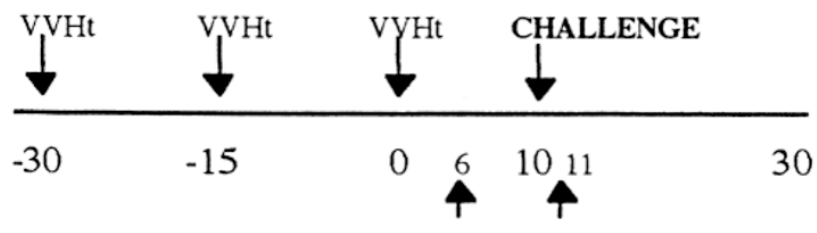

\section{C (anti asialo GM1)}

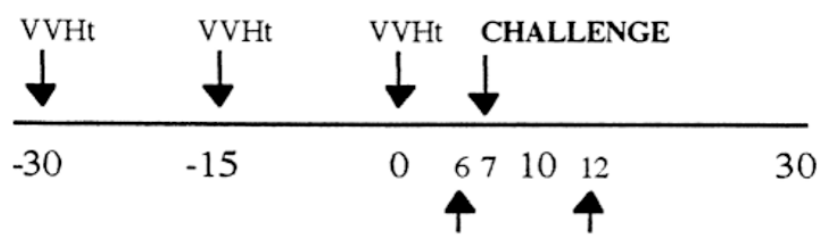

\section{D (anti IFN- $\gamma$ )}

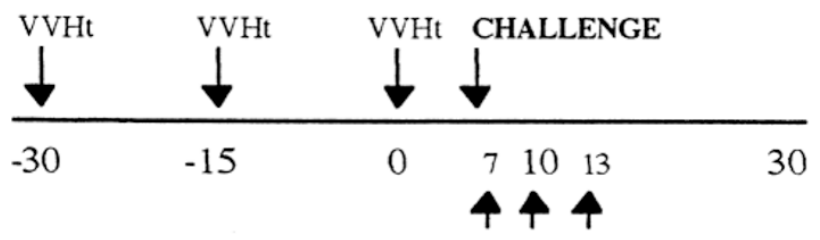

\section{E (anti FasL)}

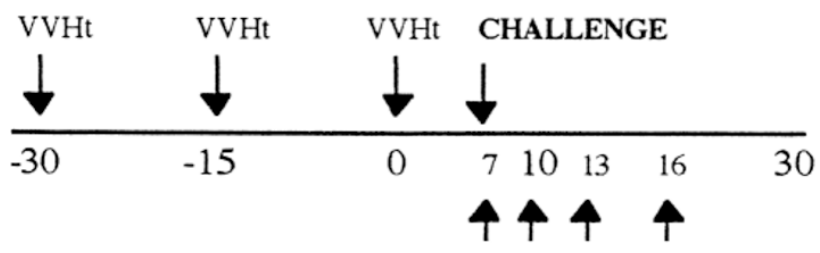

Figure 4. Blocking treatment schedules in VVHt-immunized mice. Mice were immunized as described by tail scarification and challenged (downward arrows) 7 days (C, D, E) or 10 days (A, B) after the last immunization with $40 \times 10^{6} \mathrm{IgM}-\mathrm{ARN}$ transfectoma cells. They were treated i.p. (upward arrows) with: (A) $50 \mu \mathrm{L}$ of rat ascite directed against mouse CD4 (YTS177.9.6.1) 7 and 3 days before the challenge and 4 days after; (B) $50 \mu \mathrm{L}$ of rat ascite directed against mouse CD8 (YTS105.18.10) 4 days before and 1 day after the challenge; (C) $30 \mu \mathrm{L}$ of rabbit antiasialo GM1, 1 day before and 5 days after the challenge; (D) $500 \mu \mathrm{g} /$ mouse of rat antimouse IFN $-\gamma$ $\mathrm{mAb}$ (R46A2) on the day of the challenge and $250 \mu \mathrm{g} /$ mouse twice 3 and 6 days later; (E) $0.5 \mathrm{mg} /$ mouse hamster antimouse FasL mAb (MFL1) on the day of the challenge and every following third day over a period of 9 days. 
A

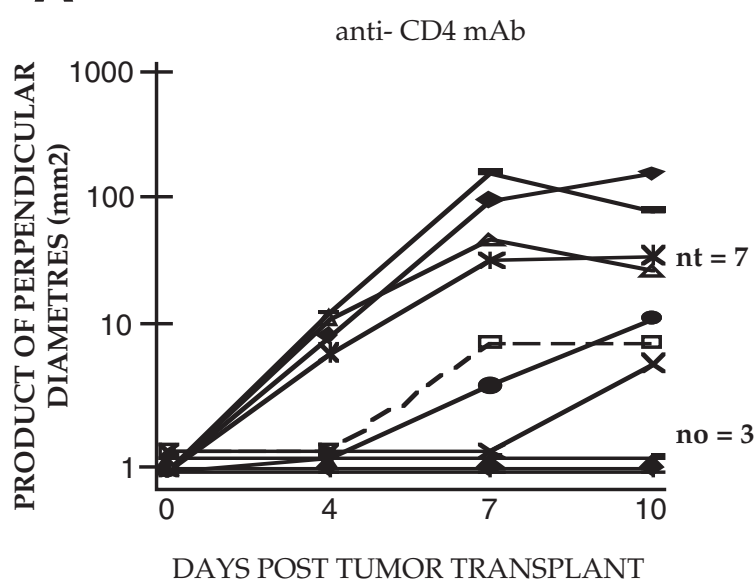

B
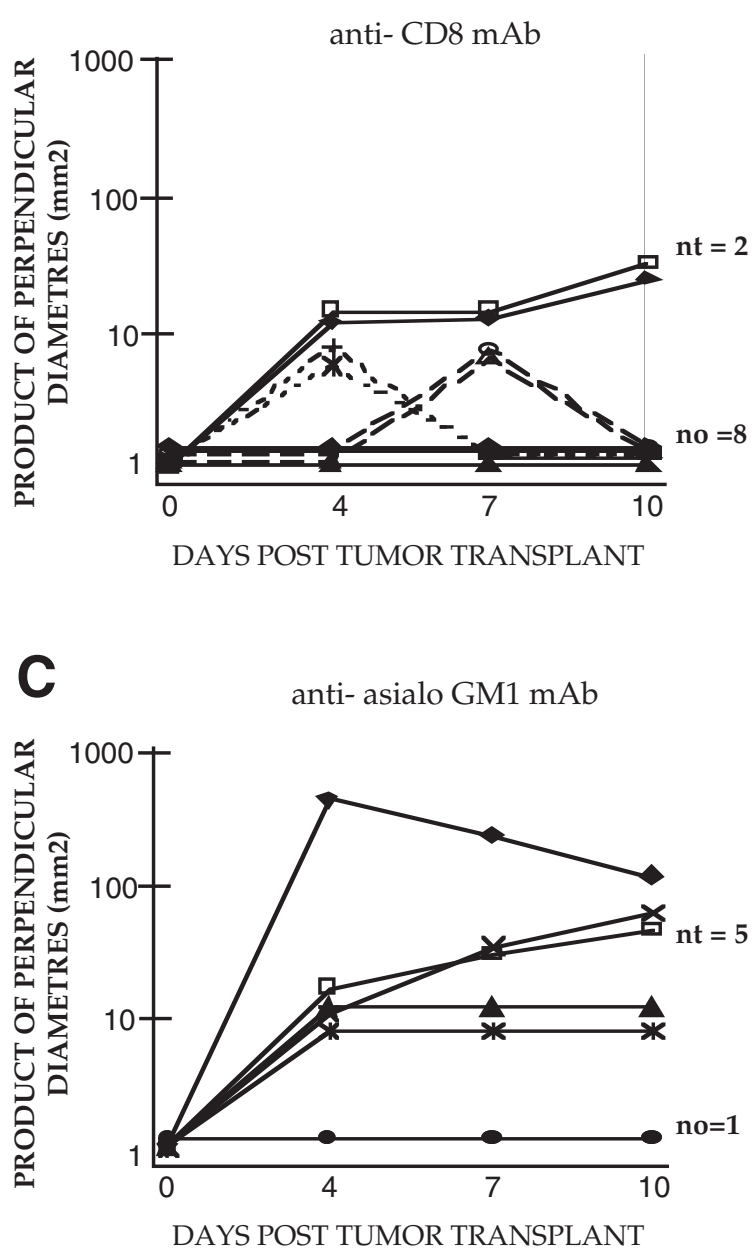

D

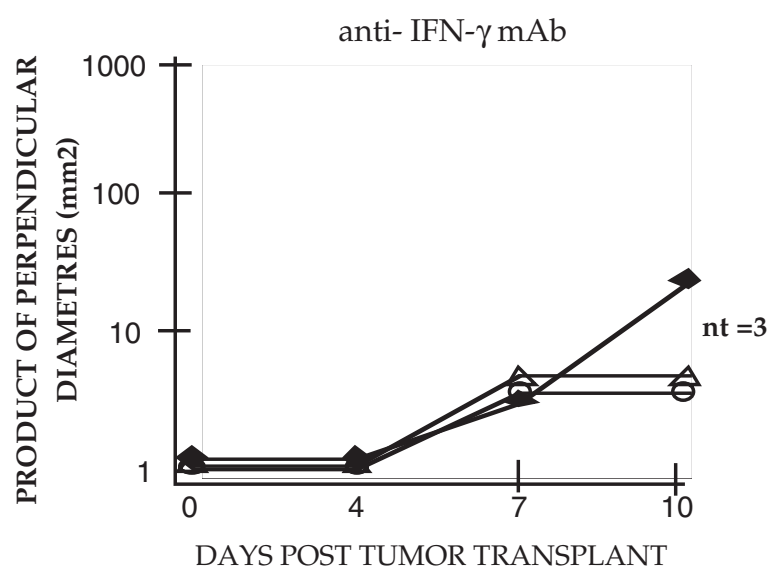

E

anti- FasL mAb

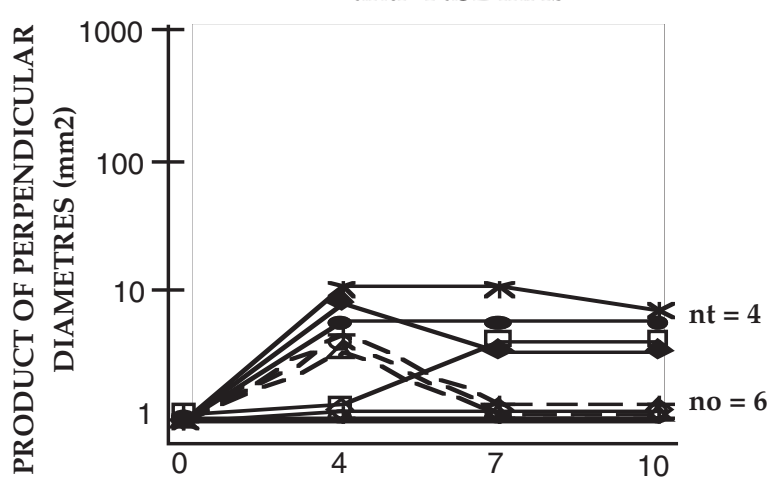

DAYS POST TUMOR TRANSPLANT

Figure 5. In vivo blocking experiments in VVHt-immunized mice. Tumor development was monitored by measuring perpendicular tumor dimensions in VVHt-immunized mice injected with IgM-ARN transfectomas and treated with: (A) antimouse CD4, (B) antimouse CD8, (C) antimouse asialo GM1 mAb, (D) antimouse IFN - $\gamma \mathrm{mAb}$, and (E) antimouse FasL mAb. The number of mice bearing tumors ( $\mathrm{nt}$ ) and the number of mice without tumors (no), 10 days after challenge, are indicated. 
activity against $\mathrm{YAC}-1$ target cells, but it also has some effects on CD8 cytotoxic activity. In VVHt-immunized mice, antiasialo GM1 treatment almost completely abolished the tumor protection (Fig 5C) $(P=.0005)$, indicating that NK cells and/or macrophages could be involved in the effector mechanisms of protection.

Tumor protection is dependent on IFN- $\gamma$ and partially on Fas-Fas ligand (Fas-FasL) interaction

Activated CD4 T cells secrete IFN- $\gamma$, which is capable of stimulating $\mathrm{NK}$ cells that can in turn produce IFN- $\gamma$ independently from cytotoxicity. ${ }^{36}$ Sixteen mice were VVHt-immunized; three were treated with an anti-IFN- $\gamma$ $\mathrm{mAb}$. We observed the appearance of tumor growth in these three animals as was the case in nonimmunized mice (Fig 5D) $(P=.0018)$.

An approach of the molecular mechanism leading to tumor protection in VVHt-treated mice was finally investigated. We decided to test the implication of FasFasL interaction because it has been shown to be involved in antitumor activity in different models ${ }^{37-40}$ and to enhance the sensitivity of tumor cell lines to Fas-mediated apoptosis. ${ }^{41}$ Because IgM-ARN transfectomas (tumor
Germline J558 CO17-1A

Germline J558 CO17-1A

Germline J558 CO17-1A

Germline J558 CO17-1A

Germline J558 CO17-1A

Germline J558 CO17-1A

Germline J558 CO17-1A

Germline DSP2.9 CO17-1A

Germline JH3 CO17-1A

Germline JH3 CO17-1A
$\begin{array}{lllllllllllllll}Q & V & Q & L & Q & Q & S & G & A & E & L & V & R & P\end{array}$

CAG GTC CAG CTG CAG CAG TCT GGA GCT GAG CTG GTA AGG CCT

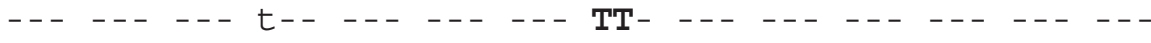

L

$\begin{array}{lllllllllllllll}G & T & S & V & K & V & S & C & K & A & S & G & Y & A\end{array}$

GGG ACT TCA GTG AAG GTG TCC TGC AAG GCT TCT GGA TAC GCC

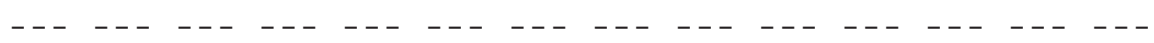

CDR1

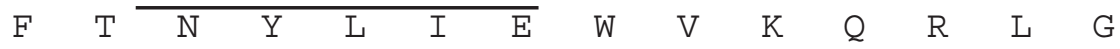

TTC ACT AAT TAC TTG ATA GAG TGG GTA AAG CAG AGG CTT GGA

-- - - - - - - - - - - - - - - - - - $-\mathrm{C}-\ldots$

$\mathrm{P}$

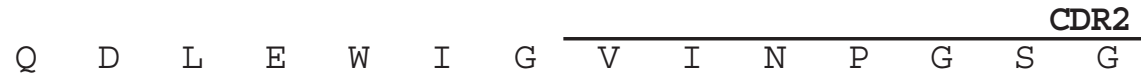

CAG GAC CTT GAG TGG ATT GGA GTG ATT AAT CCT GGA AGT GGT

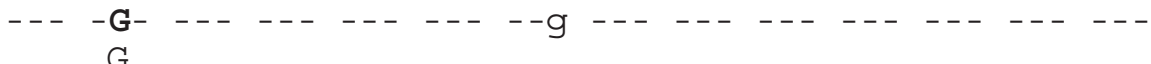

\begin{tabular}{cccccccccccccc}
\hline G & T & N & Y & N & E & K & F & K & G & K & A & T & L
\end{tabular}

GGT ACT AAC TAC AAT GAG AAG TTC AAG GGC AAG GCA ACA CTG

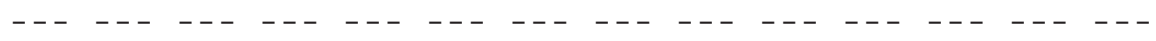

$\begin{array}{llllllllllllll}T & A & D & K & S & S & S & T & A & Y & M & Q & L & S\end{array}$

ACT GCA GAC AAA TCC TCC AGC ACT GCC TAC ATG CAG CTC AGC

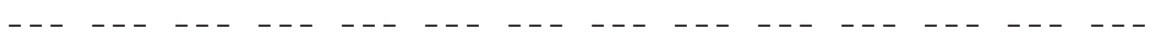

$\begin{array}{llllllllllllll}S & L & T & S & D & D & S & A & V & Y & F & C & A & R\end{array}$

AGC CTG ACA TCT GAT GAC TCT GCG GTT TAT TTC TGT GCA AGA

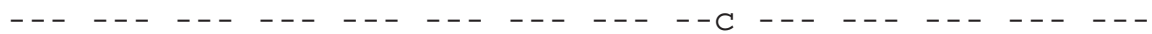

CDR3

\begin{tabular}{cc}
\hline $\mathrm{N}$ & $\mathrm{G}$ \\
GAT & GGT
\end{tabular}

- - - - -

$\begin{array}{llllllllllll}A & W & F & A & Y & W & G & Q & G & T & L & V\end{array}$ GCC TGG TTT GCT TAC TGG GGC CAA GGG ACT CTG GTC

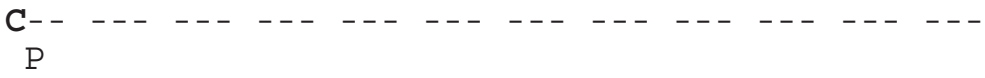

T $\quad \mathrm{V} \quad \mathrm{S} \quad \mathrm{A}$

ACT GTC TCT GCA

- - - - - - - - - -

Figure 6. Alignment of the CO17-1A heavy chain variable region nucleotide sequence with VHJ558, DSP2.9, and JH3 germline sequences. Nucleotide similarities are indicated by $(-)$, silent mutations by small letters, and replacement mutations by capital letters. The location of the CDRs is indicated. 
cells) express Fas on the cell surface (data not shown), we treated VVHt-immunized mice with an anti-FAsL $\mathrm{mAb}$ able to block Fas-FasL interaction. ${ }^{32}$ As shown in Figure 5E, the treated mice developed a significantly higher number of tumors after the challenge, but the abolition of the tumor protection was not complete $(P=.00237)$. These results could be related either to an incomplete blocking of Fas-FasL interaction or to the existence of another molecular mechanism of tumor protection.

$r V V$ expressing minimally mutated mouse $I g$ is also able to protect against tumor growth

In order to test the vaccine approach in a syngeneic model, we deliberately decided to use rVV expressing an almost germline encoded Ig, CO17-1A. The Figure 6 shows the $\mathrm{VH}$ gene derived from the frequently expressed VHJ558 family, with only three replacement mutations. If the germline gene corresponding to the $\mathrm{V} \kappa$ gene of CO17-1A is unknown, this $\mathrm{V} \kappa$ sequence is identical with the sequences reported for natural autoantibodies $\mathrm{O} 1, \mathrm{O} 4$, and $\mathrm{E} 7,{ }^{42}$ providing strong evidence that the $\mathrm{CO17-1 \textrm {A } \mathrm { V } \kappa}$ segment is directly encoded by a germline $\mathrm{V} \kappa$ gene. The 1083-17-1A hybridoma was found to elicit tumors in $100 \%$ of naive animals when s.c. injected $\left(20 \times 10^{6}\right.$ cells to three groups of 10 immunized mice and one group of 10 unimmunized mice). From days 0 to 6 , the tumors appeared in equal number in all groups, but by day 10 after tumor challenge, seven of the VVTG2179 (membrane-anchored form)-immunized mice were tumor-free and three still presented small tumors (Fig 7D). Seven of 10 of the VVTG1142 (secreted form)-immunized and 9 of 10 of the control VVGT186-immunized mice presented tumors (Fig 7, C and B) of the same size as the control unimmunized group (Fig 7A). There is a significant statistical difference, 10 days after tumor challenge, between the number of tumors in VVTG2179-immunized mice and in VVTG186-immunized animals $(P=.0022)$. Furthermore, comparison of the tumor size in these two
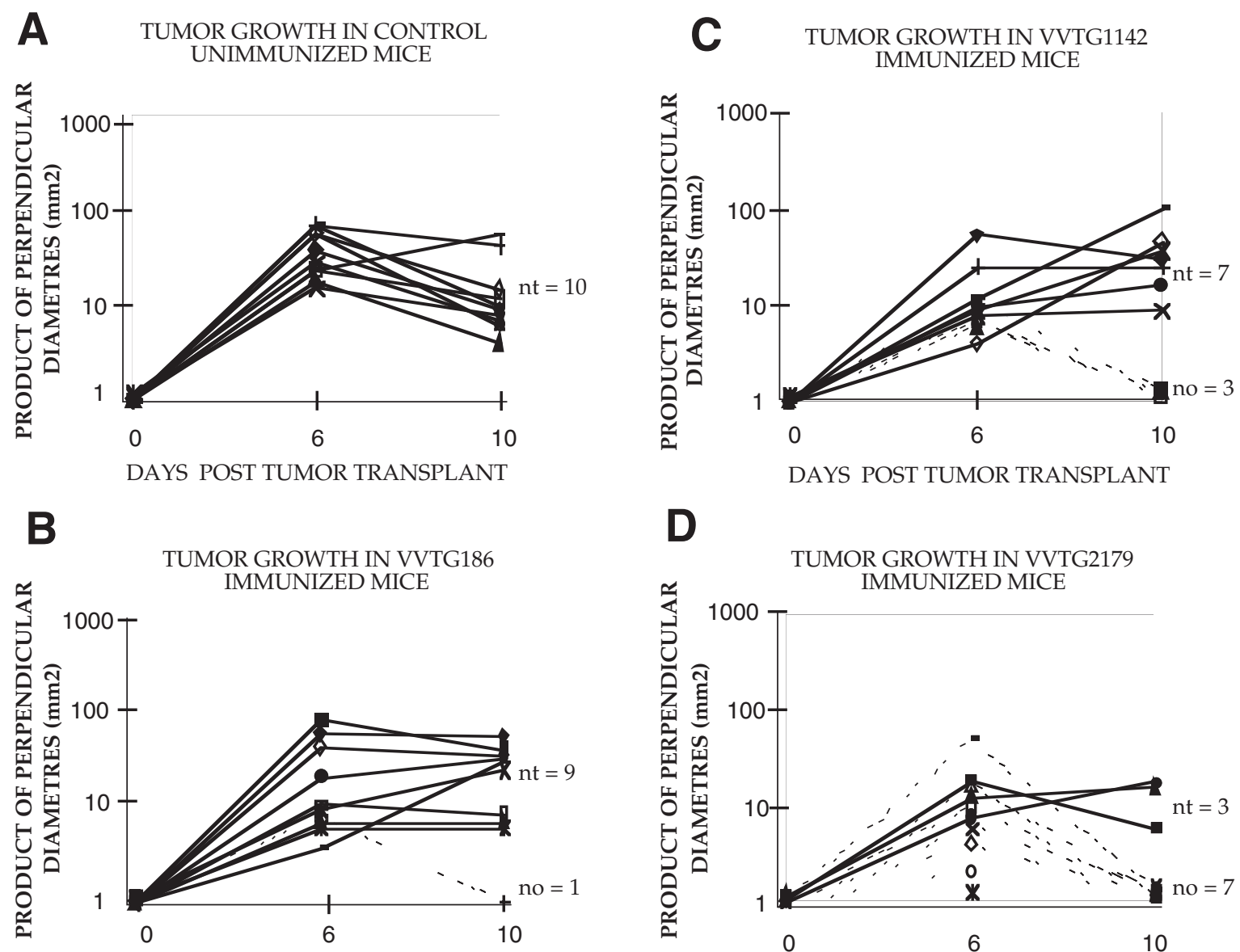



DAYS POST TUMOR TRANSPLANT

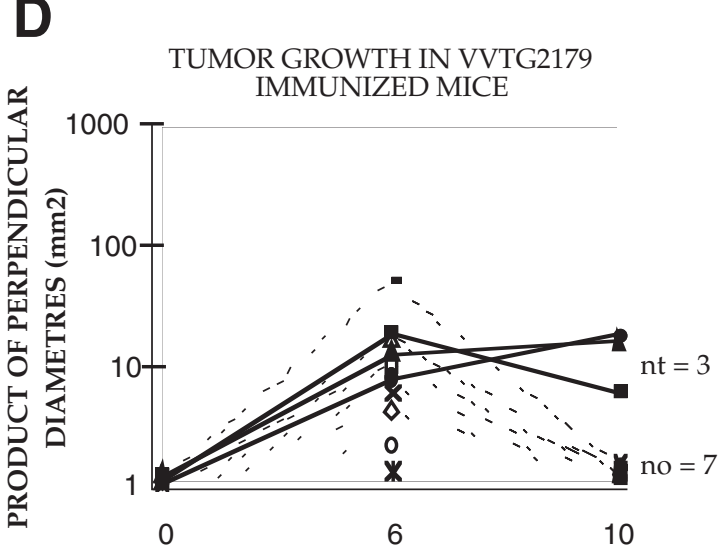

DAYS POST TUMOR TRANSPLANT

Figure 7. Antitumoral response after tumor challenge. Nonimmunized mice (A) and mice immunized with VVTG186 (wild type) (B), with VVTG1142 (secreted form) (C), and with VVTG2179 (transmembrane form) (D) were s.c. injected with $20 \times 10^{6} 1083-17-1$ A hybridoma cells at day 0 . Tumor growth was followed up by measuring perpendicular tumor dimensions with caliper. The number of mice bearing tumors ( $\mathrm{nt}$ ) and the number of mice without tumors (no), 10 days after challenge, are indicated. 
groups of mice similarly revealed a significant difference (Mann-Whitney test, $P=.0011$ ). Interestingly, the VVTG1142 expressing the secreted form of the Ig was unable to significantly affect both the number and the size of the tumors in immunized animals.

\section{DISCUSSION}

These experiments and results are directly linked to two central immunotherapy issues: finding a feasible procedure that would assure efficacious vaccination and a means of determining the relative importance of the different possible effector cells.

In the first model, the vaccination with the $\mathrm{H}$ chain construct alone was able to induce specific and complete protection against tumor growth of transfectomas expressing the same VH region. Indeed, the observed protection was specific to ARN VH because the mice were not protected when challenged with an unrelated SMI VH producing transfectoma cells. Considering the absence of secretion and of membrane presentation of ARN $\mu$ chain in BHK-21infected cells, our results suggest that the VH region was intracellularly processed during the immunization procedure in a way to promote $\mathrm{T}$-cell priming. Our first step was to test the capacity of the vaccination procedure to induce specific $\mathrm{T}$-cell proliferation and/or T-cell cytotoxicity because both of these tests have been shown to correlate with tumor protection in different experimental models, and even in clinical trials. ${ }^{43}$ In both the xenogeneic (Fig 3) and the syngeneic models (data not shown), we were unable to demonstrate any specific in vitro proliferative and/or cytotoxic responses in immunized animals, even after tumor challenge. These results are reminiscent of recently published data showing that DNA vaccination against the idiotype of a murine B-cell lymphoma does not lead to specific lymphoproliferative and cytotoxic responses. ${ }^{44}$ However, the lack of detectable in vitro cellular immune response does not necessarily mean that it does not exist in vivo: one can question the sensitivity of bulk cellular assays as opposed to limiting dilutions assays; we can also question the relevance of these in vitro tests versus in vivo experiments.

Our xenogeneic model was designed to avoid an antiidiotypic B-cell response, which is known to be able to confer tumor protection. ${ }^{12}$ Indeed, we did not observe any anti-idiotypic antibodies in the sera of immunized animals.

Anti-CD4 and anti-CD8 blocking data clearly demonstrate that CD4 $\mathrm{T}$ cells are crucial to the protection of the animals. The time dosing of the anti CD4 mAb favors the hypothesis that the effector arm of the immune response was blocked, as has already been pointed out by Greenberg $^{45}$ and more recently by Hung et al. ${ }^{46}$ However, in our model, it seems that CD4 $+\mathrm{T}$ cells were not mainly acting at enhancing in vivo the protective effect of CD8 + CTL because blocking experiments with anti-CD8 mAb did not significantly inhibit the tumor protection. Because we were unable to detect any specific CD4 $+\mathrm{T}$-cell cytotoxicity in vitro, we can hypothesize that the $\mathrm{CD} 4+\mathrm{T}$ cells recruited other effector cells such as NK cells, macrophages, or eosinophils. ${ }^{46}$ In our model, both NK cells and macrophages could be implicated because antiasialo GM1 antibodies abolished the tumor protection. The precise mechanism of action of $\mathrm{CD} 4+\mathrm{T}$ cells in tumor protection is presently unknown, but seems complex and not limited to providing signals required for the priming of MHC I restricted CD8 + T lymphocytes. In the case of vaccination of irradiated tumor cells transduced to secrete GM-CSF, ${ }^{46}$ it was shown that both Th1 and Th2 cytokines were involved in tumor protection. We tested only the blockade of IFN $-\gamma$, which, effectively, showed that the Th1 pathway was involved in the tumor protection. Apparently, these CD4+ $\mathrm{T}$ cells were able to drive effector cells that do not, by themselves, have the capacity for antigen-specific recognition to a specific target. IFN- $\gamma$ could be central to the protection mechanism because: (a) it could be produced by both CD4 T cells and NK cells; (b) it is implicated in the Th0 $\rightarrow$ Th1 differentiation; and (c) it increases FasL expression in activated cells.

Keeping in mind the goal of immunotherapy during B-CLL, where V regions are frequently germline-encoded, it was important to test the capacity of the vaccination to induce an antitumor protection in a syngeneic model where the molecular target (variable region of the Ig) was deliberately chosen being almost unmutated. In this situation, autoreactive $\mathrm{T}$ and $\mathrm{B}$ cells would undergo clonal deletion or functional anergy as a result of central or peripheral tolerance mechanisms. However, low-avidity $\mathrm{T}$ cells could escape these mechanisms and could be activated through the vaccination procedure. Our data confirm the feasibility of the rVV approach in inducing tumor protection in a syngeneic model. The efficiency of our vaccination procedure could then rely on different peculiarities: (a) the capacity of the transmembrane form of rVV to induce the presentation of $\mathrm{V}$ region-derived peptides, particularly originating from the $\mathrm{H}$ chain third complementary determining region (mainly not germline encoded); (b) the ability to activate low-avidity $\mathrm{T}$ cells able to react with self-peptides; and (c) finally, the possibility to promote Thl differentiation of effector cells and IFN $-\gamma$ production.

\section{ACKNOWLEDGMENTS}

Sémia BenAmmar-Ceccoli was supported by a fellowship from the Association de la Recherche contre le Cancer and the Ligue de Recherche contre le Cancer du HautRhin et du Bas-Rhin. The research was supported by grants from the Association de la Recherche contre le Cancer and the Ligue Nationale Française de Recherche contre le Cancer.

We thank K. Dott and E. Lozay for technical assistance; S. Chouaib for helpful discussions; C. Benoist and D. Mathis for providing 14.4.4., H97, YTS177.9.6.1, YTS105.18.10, and R46A2 antibodies; E. Vivier for the antiasialo GM1 antibody; H. Yagita for the MFL1 mAb; and R. Drillien and D. Spehner for supplying BHK-21 cells and help in VVr purification. 


\section{REFERENCES}

1. Levy R, Hatzubai A, Brown S, et al. Immunoglobulin idiotype: a tumor-specific antigen for human B-cell lymphomas. Malig Lymphomas. 1982;10:95-105.

2. George AJT, Tutt AL, Stevenson FK. Anti-idiotypic mechanisms involved in suppression of a mouse B-cell lymphoma. J Immunol. 1987;138:628-634.

3. George AJT, Folkard SG, Hamblin TJ, et al. Idiotypic vaccination as a treatment for a B-cell lymphoma. J Immunol. 1988;141:2168-2174.

4. Tao M-H, Levy R. Idiotype/granulocyte-macrophage colony-stimulating factor as a vaccine for B-cell lymphoma. Nature. 1993;362:755-758.

5. Kwak LW, Campbell MJ, Czerwinski DK, et al. Induction of immune responses in patients with B-cell lymphoma against the surface-immunoglobulin idiotype expressed by their tumors. N Engl J Med. 1992;327:1209-1215.

6. Chen T, Tao M-H, Levy R. Idiotype-cytokine fusion proteins as cancer vaccines. J Immunol. 1994;153:4775-4787.

7. Hsu FJ, Caspar CB, Czerwinski D, et al. Tumor-specific idiotype vaccines in the treatment of patients with B-cell lymphoma long-term results of a clinical trial. Blood. 1997; $89: 3129-3135$

8. Hsu FJ, Benike C, Fagnoni F, et al. Vaccination of patients with B-cell lymphoma using autologous antigen-pulsed dendritic cells. Nat Med. 1996;2:52-58.

9. Lim S, Bailey-Wood R. Idiotypic protein-pulsed dendritic cell vaccination in multiple myeloma. Int J Cancer. 1999;83: $215-222$.

10. Syrengelas A, Chen T, Levy R. DNA immunization induces protective immunity against B-cell lymphoma. Nat Med. 1996;2:1038-1041.

11. Hakim I, Levy S, Levy R. A nine-amino acid peptide from IL-1beta augments antitumor immune responses induced by protein and DNA vaccines. J Immunol. 1996;157:55035511.

12. King C, Spellerberg M, Zhu D, et al. DNA vaccines with single-chain $\mathrm{Fv}$ fused to fragment $\mathrm{C}$ of tetanus toxin induce protective immunity against lymphoma and myeloma. Nat Med. 1998;4:1281-1286.

13. Kipps TJ, Tomhave E, Chen PP, et al. Autoantibody-associated $\mathrm{K}$ light chain variable region gene expressed in chronic lymphocytic leukemia with little or no somatic mutation. $J$ Exp Med. 1988;167:840-852.

14. Kipps T, Tomhave E, Pratt L, et al. Developmentally restricted immunoglobulin heavy chain variable region gene expressed at high frequency in chronic lymphocytic leukemia. Proc Natl Acad Sci USA. 1989;86:5913-5917.

15. Meeker TC, Grimaldi JC, O'Rourke R, et al. Lack of detectable somatic hypermutation in the $\mathrm{V}$ region of the $\operatorname{IgH}$ chain gene of a human chronic lymphocytic leukemia. J Immunol. 1988;141: 3994-3998.

16. Cleary ML, Galili N, Trela M, et al. Single cell origin of bigenotypic and biphenotypic B-cell proliferations in human follicular lymphomas. J Exp Med. 1988;167:582-597.

17. Cleary ML, Meeker TC, Levy S, et al. Clustering of extensive somatic mutations in the variable region of an immunoglobulin heavy chain gene from a human B-cell lymphoma. Cell. 1986;44:97-106.

18. Moss B. Vaccinia virus: a tool for research and vaccine development. Science. 1991;252:1662-1667.

19. Moss B. Replicating and host-restricted non-replicating vaccinia virus vectors for vaccine development. Dev Biol Stand. 1994;82:55-63.

20. Perkus ME, Tartaglia J, Paoletti E. Poxvirus-based vaccine candidates for cancer, AIDS, and other infectious diseases. J Leukocyte Biol. 1995;58:1-13.

21. Moss B. Genetically engineered poxviruses for recombinant gene expression, vaccination, and safety. Proc Natl Acad Sci USA. 1996;93:11341-11348.

22. Korganow A, Martin T, Weber J, et al. Molecular analysis of rearranged $\mathrm{VH}$ genes during B-cell chronic lymphocytic leukemia: intraclonal stability is frequent but not constant. Leuk Lymphoma. 1994;14:55-69.

23. Caton AJ. Comparative sequence analysis of CO17-1A antigen-specific monoclonal antibodies. Hybridoma. 1986;5: $11-16$.

24. Sun LK, Curtis P, Rakowicz-Szulczynska E, et al. Chimeric antibody with human constant regions and mouse variable regions directed against carcinoma-associated antigen 17-1A. Proc Natl Acad Sci USA. 1987;84:214-218.

25. Kieny MP, Rautmann G, Schmitt D, et al. AIDS virus env protein expressed from a recombinant vaccinia virus. Biotechnology. 1986;4:790-795.

26. Anilionis A, Wurner WH, Curtis PJ. Structure of the glycoprotein gene in rabies virus. Nature. 1981;294:275-278.

27. Kieny MP, Lathe R, Drillien R, et al. Expression of the rabies virus glycoprotein from a recombinant vaccinia virus. Nature. 1984;312:163-166.

28. Martin T, Dully S, Carson D, et al. Evidence for somatic selection of natural autoantibodies. J Exp Med. 1992;175: 983-991.

29. Herlyn M, Steplewski Z, Herlyn D, et al. Colorectal carcinoma-specific antigen: detection by means of monoclonal antibodies. Proc Natl Acad Sci USA. 1979;76:1438-1442.

30. Herlyn DM, Steplwski Z, Herlyn MF, et al. Inhibition of growth of colorectal carcinoma in nude mice by monoclonal antibody. Cancer Res. 1980;40:717-721.

31. Cobbold S, Martin G, Waldmann H. The induction of skin graft tolerance in major histocompatibility complex-mismatched or primed recipients: primed $\mathrm{T}$ cells can be tolerized in the periphery with anti-CD4 and anti-CD8 antibodies. Eur $J$ Immunol. 1990;20:2747-2755.

32. Kayagaki N, Yamaguchi N, Nagao F, et al. Polymorphism of murine Fas ligand that affects the biological activity. Proc Natl Acad Sci USA. 1997;94:3914-3919.

33. Martin T, Crouzier R, Weber J-C, et al. Polyreactivity is dependent on somatically generated sequences in the third complementary-determining region of the antibody heavy chain. J Immunol. 1994;152:5988-5996.

34. Wang B, Gonzalez A, Benoist C, et al. The role of CD8+ T cells in the initiation of insulin-dependent diabetes mellitus. Eur J Immunol. 1996;26:1762-1769.

35. Ehl S, Nuesch R, Tanaka T, et al. A comparison of efficacy and specificity of three $\mathrm{NK}$ depleting antibodies. J Immunol Methods. 1996;199:149-153.

36. Kurago Z, Lutz C, Smith K, et al. NK cell natural cytotoxicity and IFN $-\gamma$ production are not always coordinately regulated: engagement of DX9 KIR + NK cells by HLA-B7 variants and target cells. J Immunol. 1998;160:1573-1580.

37. Arase H, Arase N, Saito T. Fas-mediated cytotoxicity by freshly isolated natural killer cells. J Exp Med. 1995;181: $1235-1238$.

38. Hanabuchi S, Koyanagi M, Kawasaki A, et al. Fas and its ligand in a general mechanism of T-cell-mediated cytotoxicity. Proc Natl Acad Sci USA. 1994;91:4930-4934.

39. Arai H, Gordon D, Nabel E, et al. Gene transfer of Fas ligand induces tumor regression in vivo. Proc Natl Acad Sci USA. 1997;94:13862-13867.

40. Tsutsui T, Mu J, Ogawa M, et al. Administration of IL-12 induces $\mathrm{CD} 3+\mathrm{CD} 4-\mathrm{CD} 8-\mathrm{B} 220+$ lymphoid population 
capable of eliciting cytolysis against Fas-positive tumor cells. J Immunol. 1997;159:2599-2605.

41. Keane M, Ettenberg S, Lowrey G, et al. Fas expression and function in normal and malignant breast cell lines. Cancer Res. 1996;56:4791-4798.

42. Asakura K, Miller DJ, Pogulis RJ, et al. Oligodendrocytereactive $\mathrm{O} 1, \mathrm{O} 4$, and $\mathrm{HNK}-1$ monoclonal antibodies are encoded by germline immunoglobulin genes. Mol Brain Res. 1995;34:283-293.

43. Massaia M, Borrione $\mathrm{P}$, Battaglio $\mathrm{S}$, et al. Idiotype vaccination in human myeloma: generation of tumor-specific immune responses after high-dose chemotherapy. Blood. 1999;94:673-683.

44. Syrengelas AD, Levy R. DNA vaccination against the idiotype of a murine B-cell lymphoma: mechanism of tumor protection. J Immunol. 1999;162:4790-4795.

45. Greenberg PD. Adoptive T cell therapy of tumors: mechanisms operative in the recognition and elimination of tumor cells. $A d v$ Immunol. 1991;49:281-355.

46. Hung K, Hayashi R, Lafond-Walker A, et al. The central role of CD4+ T cells in the antitumor immune response. J Exp Med. 1998;188:2357-2368. 